\title{
Comparison of the effects of standard and intermittent cryoimmersion on stability, pain threshold and tolerance in the ankle region in healthy individuals
}

\author{
Comparação dos efeitos da crioimersão padrão $e$ \\ intermitente sobre a estabilidade, limiar e tolerância à \\ dor na região do tornozelo em indivíduos saudáveis
}

\author{
Lenon de Paula Oliveira Arantes $\mathbb{D}^{D}$, Rafael de Medeiros Trombini $\mathbb{D}^{D}$, Yago da Silva Tobias ${ }^{\mathbb{D}}$, Thiago \\ Casali Rocha $(\mathbb{D} *$
}

Faculdade de Ciências Médicas e da Saúde de Juiz de Fora (FCMS), Juiz de Fora, MG, Brazil

\begin{abstract}
Introduction: Cryotherapy is a technique that involves the application of low temperatures in the treatment of acute injuries, with ice being the simplest and oldest therapeutic modality for this. Objective: To compare two different cold water immersion protocols (standard and intermittent) on the ankle region of healthy volunteers, we analyzed changes in static postural stability, threshold, and pain tolerance immediately after application. Method: This is a quasi-experimental study, controlled clinical trial, and non-probabilistic sampling. The total sample consisted of 40 male patients aged 18 to 30 years. Two different cold water immersion protocols (standard and intermittent) were compared for their effects on pain threshold, tolerance, and static postural stability. Results: There were no significant differences between the groups with regards to the stabilometric variables after the application of both protocols ( $p>0.05)$. There was a significant
\end{abstract}

*LPOA: BS, e-mail: lenon43@hotmail.com RMT: BS, e-mail:rtrombini5@gmail.com YST: BS, e-mail: tobiasyago96@gmail.com TCR: MS, e-mail: thiago.casali@outlook.com 
difference in the threshold and tolerance of the two groups after the application of cold water immersion $(p<0.05)$; however, there were no significant differences between the groups $(p>0.05)$. Conclusion: Both cold water immersion protocols proved to be safe for static postural balance, without showing deficits in stabilometric variables. Regarding the analgesic effect, both were effective and significantly increased the threshold and tolerance of ankle pain after cryoimmersion, without any differences between groups. Thus, intermittent 10-minute cold water immersion is sufficient to generate the same analgesic effect as the standard 20-minute pattern, with no change in static postural stability.

Keywords: Cryotherapy. Musculoskeletal Pain. Pain Tolerance. Postural Balance.

\section{Resumo}

Introdução: A crioterapia é uma técnica que consiste na aplicação de temperaturas mais baixas, sendo o gelo, a modalidade terapêutica mais simples e antiga no tratamento de lesões agudas. Objetivo: Comparar dois protocolos diferentes de crioimersão (padrão e intermitente) sobre a região do tornozelo de voluntários saudáveis, analisando as alterações na estabilidade postural estática e no limiar e tolerância à dor, imediatamente após a aplicação. Método: Trata-se de um estudo de natureza quasi-experimental, do tipo ensaio clínico controlado, com amostragem não probabilística. A amostra total foi constituída de 40 indivíduos do sexo masculino com idade entre 18 e 30 anos, comparando dois protocolos diferentes de crioimersão (padrão e intermitente) e seus efeitos sobre o limiar e tolerância à dor, e estabilidade postural estática. Resultados: Não houve diferenças significativas em relação as variáveis estabilométricas após a aplicação de ambos os protocolos $(p>0,05)$. Houve diferença significativa no limiar e tolerância dos dois grupos após a aplicação da crioimersão $(p<0,05)$, entretanto sem diferenças significativas entre os grupos $(p>0,05)$. Conclusão: Os dois protocolos de crioimersão se mostraram seguros com relação ao equilíbrio postural estático, sem apresentar déficits nas variáveis estabilométricas. Com relação ao efeito analgésico, ambos foram eficazes, aumentando significativamente o limiar e a tolerância de dor no tornozelo após a crioimersão, sem que houvesse diferenças entre os grupos. Dessa forma, percebe-se que a crioimersão intermitente de 10 minutos é suficiente para gerar o mesmo efeito analgésico que a padrão de 20 minutos, sem alteração na estabilidade postural estática.

Palavras-chave: Crioterapia. Dor Musculoesquelética. Tolerância à Dor. Equilíbrio Postural.

\section{Introduction}

Ankle sprains are considered to be one of the most common sports-related injuries, comprising about $30 \%$ of all sports injuries [1]. About $85 \%$ of ankle sprains correspond to inversion sprains [2]. Worldwide, it is estimated that 1 in 10,000 people sprain their ankle every day [3]. Thus, cryotherapy is used to promote faster recovery from these injuries, aiming to accelerate the patient's return to normal activities [4].

Cryotherapy involves the application of lower temperature, with ice being the simplest and oldest therapeutic modality in the treatment of acute injuries [5]. After its application, there is primarily a reduction of inflammation and pain (by increasing the threshold and pain tolerance), assisting in the retrieval action [6-9].
Cryotherapy can be applied in several ways, such as immersion in cold water [10-13], thermoelectric cooling [14,15], and ice packs [16], applied from 15 to 30 minutes [17]. Moreover, another study suggested that intermittent application of cryotherapy for $10 \mathrm{~min}$ is sufficient to reduce skin and deep tissue temperature to optimal therapeutic levels, promoting analgesia, with ice considered as the safest and most efficient method of application [18]. On the other hand, according to Rupp et al. [19], when the use of ice was compared to immersion in cold water in the gastrocnemius muscle, it was less efficient in reducing the intramuscular temperature during treatment and after $90 \mathrm{~min}$. Furthermore, in another study, cryotherapy with intermittent application 
for 10 min was related to a longer maintenance of optimal tissue temperature levels compared to the standard application for $20 \mathrm{~min}$ [18,20]. According to Chesterton etal. [21], to obtain a desirable physiological pain reduction response with cryotherapy, it is necessary for the skin tissue to reach temperature levels below $13.6^{\circ} \mathrm{C}$.

It was also shown that cryotherapy can reduce nerve conduction speed, and is undesirable before exercise due to the reduction of neuromuscular control. It is negatively related to static postural stability, which may represent a greater risk of injury to the lower limb approximately 30 minutes after application [8,11,22-28]. In another study, the stability did not change [29].

One way of assessing this stability is through the stabilometer, a method considered to be the gold standard. This device consists of quantifying body oscillations while the individual remains standing on a force platform, which analyzes the displacement of the pressure center in the anterior-posterior and lateral-lateral directions [30].

Given this paradoxical information in the literature, the best method of application for pain relief and its effects on stability are still largely controversial. Thus, the aim of this study was to compare two different cryoimmersion protocols (standard and intermittent) in the ankle region of healthy volunteers, and to analyze the changes in static postural stability and threshold and tolerance to pain immediately after application.

\section{Method}

This was a quasi-experimental study, with a clinical trial involving non-probabilistic sampling. The total sample consisted of 41 men aged 18 to 30 , who were excluded if they met any of following criteria: (1) selfreported joint pain, (2) previous history of injuries to the ankle joint, (3) presence of prostheses or orthoses, (4) previous surgeries in the ankle region, (5) presence of Raynaud's phenomenon, cold hives, cryoglobulinemia, cold hemoglobinuria, peripheral vascular disease, hypersensitivity to cold, diabetes mellitus, or any inflammatory process in the ankle area, and (6) use of drugs that may interfere with stability and posture, or cause neurological diseases, vestibular, cognitive and visual changes without using corrective methods.

Initial contact was made with each of the volunteers, with a brief explanation of the procedure and the exclusion criteria mentioned above; this was necessary for participation. Eligible participants were asked to appear at the research site after setting 1-hour morning appointments, where a detailed explanation of the two cryotherapy protocols and their respective assessments was carried out. The participants were grouped in predefined order, alternating between groups, wherein the first participant was allocated to the intermittent group (G10), the second was allocated to the standard group (G20), and so on.

Afterwards, they signed the Informed Consent Form (TCLE). The study was approved by the CEP of the Faculty of Medical and Health Sciences of Juiz de Fora - SUPREMA, with CAAE 82823517.1.0000.5103. Data was collected on different mornings from August to September 2019, at the Faculty of Medical Sciences and Juiz de Fora Health - SUPREME, in an environment with an average temperature of $18,4{ }^{\circ} \mathrm{C} \pm 3.58$ and relative humidity of $76.96 \% \pm 12.61$ [31].

Data collection took place through an anamnesis developed by the evaluators, containing questions such as name, foot size, age, race, color, contact number, profession, e-mail, dominant lower limb, medication/s, weight, height (measured by a Welmy balance W200 model / 5), and body mass index (IMC).

For both groups, prior to immersion, skin temperature was measured bilaterally in the ankle $1 \mathrm{~cm}$ caudal to the lateral malleolus, using a Smart Sensor ${ }^{\circledR}$ Infrared Thermometer AR360A+. This device has a standard deviation of $3^{\circ} \mathrm{C}$ for temperatures ranging from 50 to $0^{\circ} \mathrm{C}$, and $2^{\circ} \mathrm{C}$ for temperatures from 0 to $100^{\circ} \mathrm{C}$, with an ability to obtain $95 \%$ of the final temperature result in $500 \mathrm{~ms}$. This was applied in contact with the skin and maintained for $5 \mathrm{~s}$.

As for the pain threshold (when the painful sensation starts) and the pain tolerance (when it becomes unbearable), they were manually evaluated with a 20 kgf/200N - Crown-At Linear Tubular pressure algometer applied to the ankle region in the same place where the temperature was assessed, perpendicular to the skin.

Then, an assessment of static postural balance was performed using a Podaly ${ }^{\circledR}$ electronic baropodometric S-PLATE device manufactured in Brazil, with a force platform with 1600 sensors and an active surface of 400 $\times 400 \mathrm{~mm}$, with dimensions of $610 \times 580 \times 40 \mathrm{~mm}$, connected to a notebook processor with $1.80 \mathrm{GHz}$ and 4,00 GB of RAM. Individuals were instructed to remain silent and stable in a comfortable upright position, within the catchment area force platform. The upper limbs were relaxed and parallel to the body, the head was placed 
in a neutral position with a fixed gaze, and all objects and accessories, including shoes, were removed. The participant's positioning on the platform was photographed, to be replicated in later evaluations. After all these adjustments, the patient was instructed to remain as stable as possible, and 300 images were taken in 30 seconds using the platform's own software [32,33].

After carrying out the evaluations, a Plasvale basin (38 $\mathrm{L}$ and $27 \mathrm{~cm}$ deep) was filled with water until the $15 \mathrm{~cm}$ mark, then ice cubes were placed until the temperature dropped to around 4 to $6^{\circ} \mathrm{C}$ [12] as evaluated by the infrared thermometer positioned as close to the water surface at the edge of the basin. Due to the water level increase from the ice cubes, water was removed to reach the $15 \mathrm{~cm}$ mark. Whenever the temperature was higher, more ice cubes were added, and when it was lower, $290 \mathrm{~mL}$ of cold water was replaced with $290 \mathrm{~mL}$ of room temperature water, until the stipulated temperature was again reached.

Immediately afterwards, the feet of the participant was immersed, with the participant seated in a chair, ankle at a neutral position $\left(90^{\circ}\right)$, and heels separated at a distance of $2 \mathrm{~cm}$ and an angle of $30^{\circ}$ of opening of the feet. Again, the amount of water needed to return to a depth of $15 \mathrm{~cm}$ of immersion was removed, and immediately afterwards, the respective protocol (G10 or G20) was performed. Every minute, the water temperature was reassessed and adjusted as described above.

The volunteers in G20 underwent standard cryotherapy protocol of 20 minutes of immersion, as recommended in previous literature $[6,20]$. On the other hand, the volunteers in G10 underwent intermittent cryotherapy protocol, which is comprised of $10 \mathrm{~min}$ of immersion, followed by a 10 min interval wherein the immersed limbs that were dried with a towel, and immediately afterwards the skin temperature, threshold and tolerance to pain, and static balance were measured, and finally, another $10 \mathrm{~min}$ of immersion.

After the end of both procedures, either G10 or G20, the limbs that were immersed in the water were dried with a towel and, immediately afterwards, all evaluations done prior to immersion were repeated.

For data analysis, the normality and homoscedasticity of the distribution was initially validated using parametric statistics. The data was presented as the mean \pm standard deviation for descriptive statistics. To compare the effect of cold water immersion on the stability and balance of stabilometric variables before and after applying ice to G10 and G20, the paired t-test and ANOVA were used. To compare the effect of ice on pain threshold and tolerance, we used the one-way ANOVA test.

All analyses were performed using the GraphPad Prism 5 software (2015), with a significance level set to $5 \%$.

\section{Results}

The results were analyzed from a sample consisting of 41 volunteers who were willing to undergo the protocol of G10 or G20. One of these participants was excluded from the sample because he did not tolerate cryoimmersion for more than $37 \mathrm{~s}$. The descriptive analysis of the sample is shown in Table 1.

Table 1 - Characteristics of individuals from G20 $(n=20)$ and G10 $(n=20)$

\begin{tabular}{|c|c|c|c|}
\hline \multicolumn{4}{|c|}{ Values } \\
\hline Variable & G20 & G10 & P-value \\
\hline Age (years) & $21.45 \pm 2.74(19$ e 27$)$ & $20.70 \pm 1.59(19$ e 25$)$ & 0.297 \\
\hline Weight (kg) & $78.82 \pm 14.04(57.8$ e 119.3$)$ & $81.56 \pm 15.02$ (65.4 e 129.8$)$ & 0.555 \\
\hline Height (m) & $1.75 \pm 0.07(1.65$ e 1.89$)$ & $1.77 \pm 0.07(1.63$ e 1.91$)$ & 0.477 \\
\hline BMI $\left(\mathrm{kg} / \mathrm{m}^{2}\right)$ & $25.53 \pm 3.40(20.89$ e 33.75$)$ & $26.14 \pm 5.17$ (21.1 e 44.4$)$ & 0.666 \\
\hline Foot size (Brazilian System) & $41.2 \pm 1.33(38$ e 44$)$ & $41.9 \pm 1.92(39$ e 46$)$ & 0.221 \\
\hline
\end{tabular}

Note: $\mathrm{Kg}=$ kilogram; $\mathrm{m}=$ meters; $\mathrm{BMI}=$ body mass index.

Analysis was performed using the paired t-test and ANOVA, and cryoimmersion was verified to be significant for the reduction of the skin temperature bilaterally, in both groups $(p<0.05)$ even after only 10 min of application. Using the ANOVA test to analyze the moments after application of cryotherapy (G20 and G10) and the G10 interval time showed no differences between the groups $(\mathrm{p}=0.149)$. This data is shown in Table 2 . 
Table 2 - Skin temperature in Group Standard and Group Flashing

\begin{tabular}{|c|c|c|c|c|c|}
\hline & $\mathrm{N}=\mathbf{2 0}$ & Before & & After & P-Value \\
\hline \multirow{3}{*}{ G20 } & $\begin{array}{l}\text { Temperature }\left({ }^{\circ} \mathrm{C}\right) \\
\text { Left foot }\end{array}$ & $28.8 \pm 3.01$ & & $9.41 \pm 1.64$ & $p<0.001$ \\
\hline & $\begin{array}{l}\text { Temperature }\left({ }^{\circ} \mathrm{C}\right) \\
\text { Right foot }\end{array}$ & $28.92 \pm 2.37$ & & $9.43 \pm 1.48$ & $p<0.001$ \\
\hline & $N=20$ & Before & $\begin{array}{l}\text { Interval } \\
\text { (10 min) }\end{array}$ & After & P-Value \\
\hline \multirow{2}{*}{ G10 } & $\begin{array}{l}\text { Temperature }\left({ }^{\circ} \mathrm{C}\right) \\
\text { Left foot }\end{array}$ & $28.63 \pm 2.28$ & $10.31 \pm 1.53$ & $9.5 \pm 1.63$ & $p<0.001$ \\
\hline & $\begin{array}{l}\text { Temperature }\left({ }^{\circ} \mathrm{C}\right) \\
\text { Right foot }\end{array}$ & $29.03 \pm 2.29$ & $10.38 \pm 1.69$ & $9.53 \pm 1.54$ & $p<0.001$ \\
\hline
\end{tabular}

After analysis using the paired t-test and ANOVA, we found that cryoimmersion for both G20 and G10 did not cause a significant active difference $(p>0.05)$ when evaluated with stabilometric variables before, during the interval, and after cryotherapy. This data is observed in Table 3.

Table 3 - FStabilometric data before and after ice application for G20 and G10

\begin{tabular}{|c|c|c|c|c|c|}
\hline & $\mathrm{N}=\mathbf{2 0}$ & Before & & After & P-Value \\
\hline \multirow{7}{*}{ G20 } & Length & $68.84 \pm 21.48$ & & $73.95 \pm 27.03$ & 0.329 \\
\hline & Area & $51.14 \pm 45.57$ & & $59.83 \pm 58.92$ & 0.499 \\
\hline & Lateral-lateral width & $7.16 \pm 3.19$ & & $7.32 \pm 4.10$ & 0.874 \\
\hline & Average lateral-lateral speed & $1.75 \pm 0.55$ & & $1.89 \pm 0.66$ & 0.286 \\
\hline & Anteroposterior width & $8.35 \pm 4.39$ & & $8.41 \pm 5.67$ & 0.955 \\
\hline & Anteroposterior mean speed & $1.18 \pm 0.39$ & & $1.26 \pm 0.53$ & 0.407 \\
\hline & $\mathrm{N}=\mathbf{2 0}$ & Before & $\begin{array}{l}\text { Interval } \\
(10 \mathrm{~min}) \\
\end{array}$ & After & P-Value \\
\hline \multirow{6}{*}{ G10 } & Length & $64.6 \pm 11.46$ & $63.72 \pm 15.13$ & $62.6 \pm 13.83$ & 0.892 \\
\hline & Area & $36.8 \pm 29.8$ & $40.86 \pm 31.33$ & $38.8 \pm 35.9$ & 0.925 \\
\hline & Lateral-lateral width & $6.07 \pm 3.08$ & $6.42 \pm 2.58$ & $6.51 \pm 3.57$ & 0.894 \\
\hline & Average lateral-lateral speed & $1.67 \pm 0.23$ & $1.65 \pm 0.37$ & $1.63 \pm 0.36$ & 0.927 \\
\hline & Anteroposterior width & $6.99 \pm 2.85$ & $7.39 \pm 3.48$ & $6.55 \pm 3.0$ & 0.701 \\
\hline & Anteroposterior mean speed & $1.07 \pm 0.33$ & $1.05 \pm 0.32$ & $1.17 \pm 0.72$ & 0.700 \\
\hline
\end{tabular}

Figure 1 represents the bilateral pain threshold and tolerance before and after cold water immersion of G10 and G20. For G20, a paired t-test revealed that the two variables increased statistically significantly $(p<0.05)$, without showing differences between feet ( $p>0.05$ ). By analyzing G10 using an ANOVA test and then a paired t-test, we found statistically significant differences between pre-cryoimmersion and the interval time as well as between pre-cryoimmersion and post-cryoimmersion $(\mathrm{p}<0.05)$.
However, no significant differences were observed between the post-cryoimmersion interval and between the feet $(p>0.05)$.

Figure 2 shows the comparison between groups (G20 and G10) of pain threshold and tolerance (using the mean of the two feet). After comparing the groups before and after cryoimmersion, as well as comparing G20 post-cryoimmersion with G10 during the interval time, no statistically significant differences were found between the groups in any of the analyses ( $p>0.05$ ). 
Pain threshold in G20

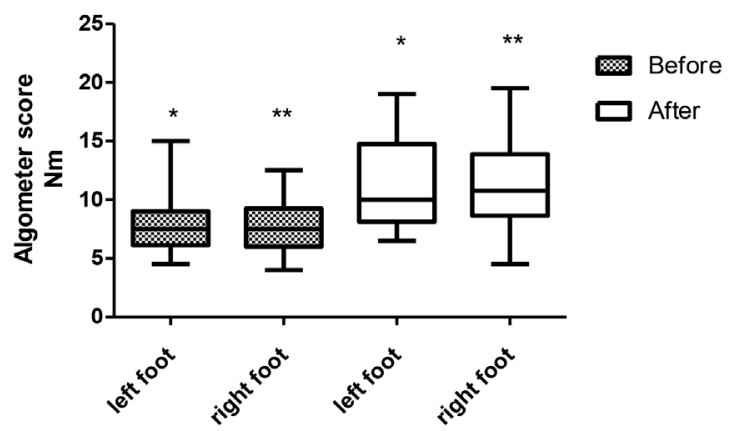

Pain threshold in the G10

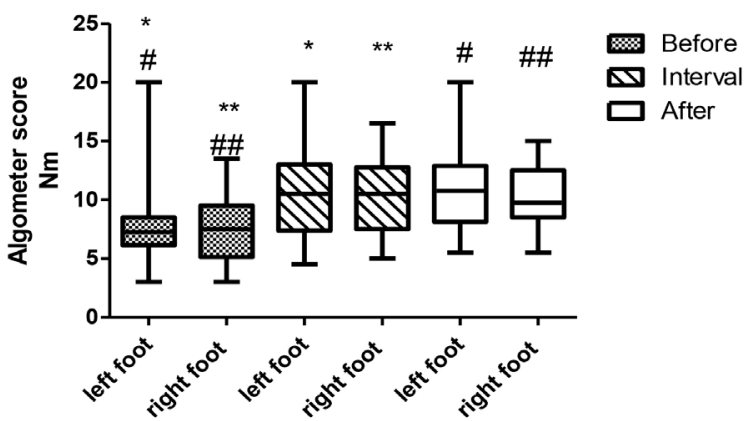

Pain tolerance in the G20

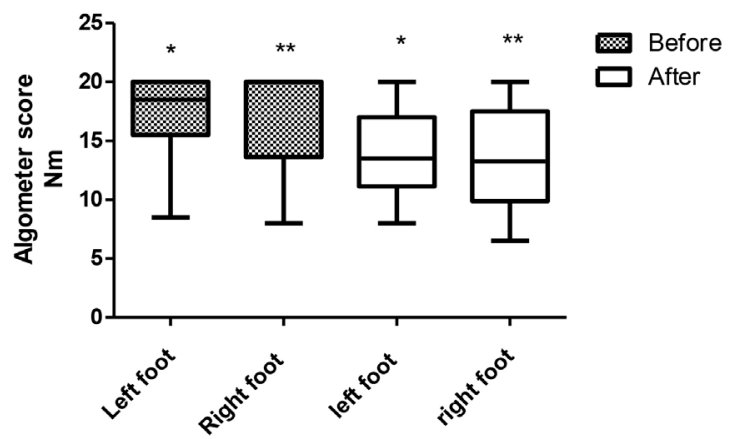

Pain tolerance in the $\mathbf{G 1 0}$

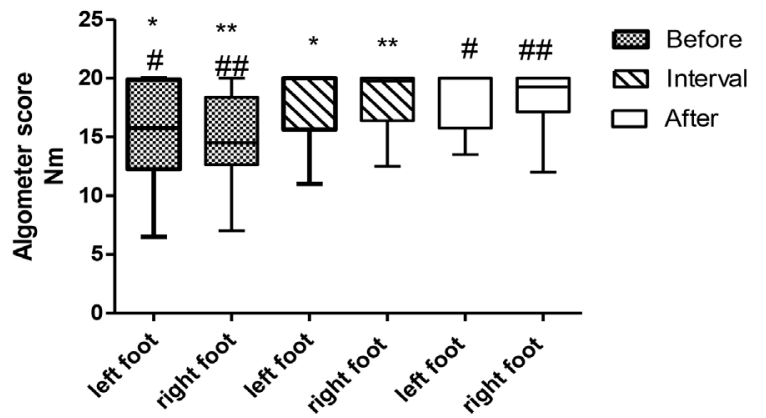

Figure 1 - Pre- and post-cryoimmersion pain threshold and tolerance in G20 and G10.

Note: ${ }^{*}=(p<0.05)$ from before immersion to after immersion of the left foot; ${ }^{* *}=(p<0.05)$ from before immersion to after immersion of the right foot; $\#=(p<0.05)$ from before immersion to after immersion of the left foot; \#\# $=(p<0.05)$ from before immersion to after immersion of the right foot.

G20 versus $\mathbf{G 1 0}$ pain threshold

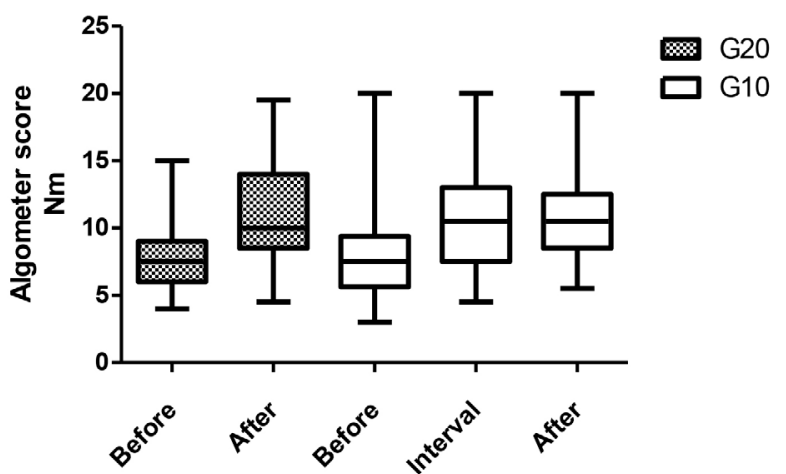

Pain tolerance $\mathbf{G} 20$ versus $\mathbf{G 1 0}$

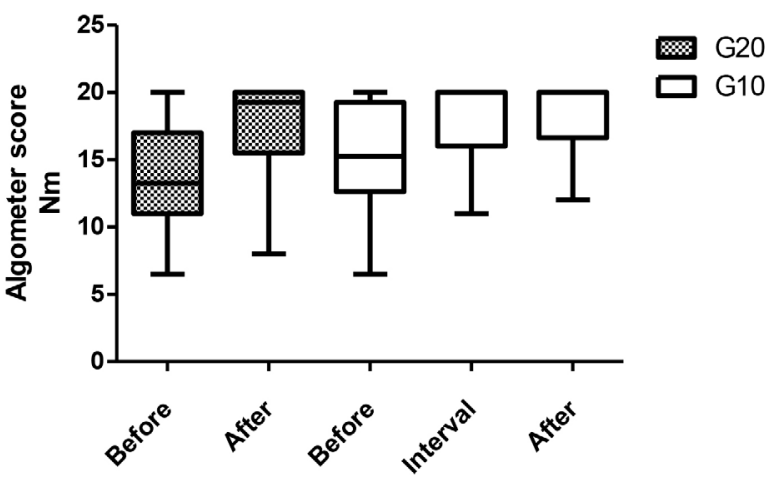

Figure 2 - Comparison of threshold and pain tolerance of G20 and G10.

\section{Discussion}

It was expected that both cryotherapy protocols (standard and intermittent) would promote an increase in pain threshold and tolerance without significant differences between the two. This hypothesis was confirmed in the results, and suggests that 10-min cryoimmersion generates the same hypoalgesia effect as a 20 -min application.

Regarding stabilometry, it was hypothesized that, after cryoimmersion in G20, there would be an increase in the values of stabilometric variables (both anterolateral 
and anteroposterior), indicating a worsening of static balance. This was seen in a recent clinical trial evaluating healthy young individuals with no history of musculoskeletal injuries, similar to the present study [28]; and even if this increase did not occur in the G10. However, no significant differences in the stabilometric variables were observed before and after cryoimmersion, or between the groups either, suggesting that cryoimmersion did not affect static balance. These results do not corroborate the impressions obtained by Macedo et al. [34], who verified the following responses in healthy athletes: decreased electromyographic signal from the gastrocnemius muscle, worsened vertical jump performance, and impaired static balance.

Regarding the skin temperature, it was verified that values below $13.6^{\circ} \mathrm{C}$ are already capable of generating an adequate analgesic effect [21]. Such a phenomenon was observed in our findings, both for G20 and G10. Another point to be noted is the time required to reach the minimum skin temperature; a survey conducted by Janwantanakul et al. [35] found that 10 minutes of intervention is already sufficient to achieve such an effect. Our results do not confirm this premise because in G20, the skin temperature values were lower than the values in the G10 interval, although they were not significantly different. However, this was not clinically relevant, as both protocols achieved the same effects on pain threshold and tolerance.

Among the various effects of cryotherapy, it should be noted that its use was related to the reduction of the inflammatory process and, consequently, pain [6-9]. This happens through the reduction of the action of the enzymes phospholipase $\mathrm{C}$ and phospholipase $\mathrm{A} 2$ when exposed to low temperatures, thus reducing the biosynthesis of prostaglandins, which are important inflammatory mediators [36]. Moreover, studies suggest that the increase in pain threshold and tolerance may be related to the reduction in the nerve conduction speed of the harmful stimulus after the local cooling of the tissues $[22,37,38]$. The decrease in neuronal metabolism and sodium-potassium pump activity, increases the excitability threshold of sensory neurons at the application site, thus increasing the refractory period [39]. This reduction in pain levels can also occur by reducing the release of endorphins [38]

Although this technique seeks to decrease the speed of nerve conduction as a form of pain relief, it may be undesirable before exercise or training, as some studies suggest that its application may affect proprioception [40-42] and motor control [27], as it can cause a reduction in muscle torque, thereby increasing the risk of injuries [24,25].

Studies have sought to determine the effects of cryotherapy on proprioception, defined as the ability of an individual to feel the joint position, movement, and strength of the limbs $[43,44]$. Cryotherapy can reduce the activity of the muscle spindle and Golgi tendon organs as well as the proprioceptors located in the soft tissue [45]. There is great importance in maintaining proprioceptive acuity, as it is an essential component in the prevention and rehabilitation of injuries and is often ignored, resulting in undesirable consequences [5,46-48].

Studies have corroborated the idea that after cryotherapy, the sense of joint position was unaffected [4952]; however, other research groups have reported its worsening [40-42]. Furmanek et al. [45] studied two proprioceptive components after the application of cryotherapy: the joint position sense and the sense of production and reproduction of force; and cryotherapy was found to be safe before physical activity.

Bleakley et al. [20] also reported low levels of pain after two cryotherapy protocols (intermittent pattern), using the Visual Analog Scale (VAS) in subjects with mild or moderate sprained ankles within the past 48 hours. Both groups showed a reduction in pain levels, corroborating our findings; however, in their study, there was a statistically significant superiority of the intermittent group.

In the same sense, in order to assess the effects of different forms of application of cryoimmersion, Freire et al. [37] user plowing one baropodometer to evaluate static balance 32 in indoor soccer players after cold water immersion for $10 \mathrm{~min}$ at different temperatures, and found no significant differences within and between groups, as observed in our study.

Based on the above, the present study provides perspectives on the protocol for the application of cryoimmersion. Based on these findings, we consider that cryotherapy flashing for $10 \mathrm{~min}$ has the same analgesic effect as the standard protocol. Thus, the application time can be optimized, allowing for interventions during the interval, providing a longer cooling period, and two possibilities of mobilization with the analgesic effect. In addition, no significant intra- and intergroup differences were observed regarding stabilometric variables, and neither protocol altered static postural stability.

As a limitation of the study, the device used to assess pain threshold and tolerance, which has an upper limit of $20 \mathrm{kgf}$, may underestimate the results. Standardizing 
the depth of the basin to $15 \mathrm{~cm}$ to control the water temperature, when the literature describes $20 \mathrm{~cm}$ as the standard, may have influenced the static postural stability because it reaches a smaller muscle portion and, consequently has less proprioceptive receptors [53]. The assessment of static balance was carried out immediately after application of the protocol; this failed to consider that the cooling peak of deep tissues will occur after the end of the intervention, as they will continue to lose heat to the most superficial tissues $[19,54]$. The way used to standardize the positioning of the feet on the stabilometer, in the evaluation and reassessment (photo) may not be very reliable, and may cause bias in the stabilometric values. Lastly, in the absence of evaluation of the proprioceptive components, we suggest that further studies assess the sense of joint position, strength and movement of the ankle joint.

\section{Conclusion}

Intermittent cold water immersion for $10 \mathrm{~min}$ achieved the same increase in the threshold and tolerance of pain when compared to standard cold water immersion for 20 minutes, without causing changes in balance, and can optimize the time of therapy associated with the possibility of intervention between applications.

\section{References}

1. Waterman BR, Owens BD, Davey S, Zacchilli MA, Belmont Jr PJ. The epidemiology of ankle sprains in the United States. J Bone Joint Surg Am. 2010;92(13):2279-84.

2. Ferran NA, Maffulli N. Epidemiology of sprains of the lateral ankle ligament complex. Foot Ankle Clin. 2006;11(3):659-62.

3. Waterman BR, Belmont Jr PJ, Cameron KL, Deberardino TM, Owens BD. Epidemiology of ankle sprain at the United States Military Academy. Am J Sports Med. 2010;38(4):797-803.

4. Fullam K, Caulfield B, Coughlan GF, McGroarty M, Delahunt E. Dynamic postural-stability deficits after cryotherapy to the ankle joint. J Athl Train. 2015;50(9):893-904.
5. Bleakley C, McDonough S, MacAuley D. The use of ice in the treatment of acute soft-tissue injury: a systematic review of randomized controlled trials. Am J Sports Med. 2004;32(1):251-61.

6. Swenson C, Sward L, Karlsson J. Cryotherapy in sports medicine. Scand J Med Sci Sports. 1996;6(4):193-200.

7. Vaile J, Halson S, Gill N, Dawson B. Efecct of hydrotherapy on the signs and symptoms of delayed onset muscle soreness. Eur J Appl Physiol. 2008;102(4):447-55.

8. Algafly AA, George KP. The effect of cryotherapy on nerve conduction velocity, pain threshold and pain tolerance. Br J Sports Med. 2007;41(6):365-9.

9. Merrick MA. Secondary injury after musculoskeletal trauma: a review and update. J Athl Train. 2002;37(2):209-17.

10. Thain PK, Bleakley CM, Mitchell AC. Muscle reaction time during a simulated lateral ankle sprain after wetice application or cold-water immersion. J Athl Train. 2015;50(7):697-703.

11. Macedo CSG, Alonso CS, Liporaci RF, Vieira F, Guirro RRJ. Cold water immersion of the ankle decreases neuromuscular response of lower limb after inversion movement. Braz J Phys Ther. 2014;18(1):93-7.

12. Macedo CS, Vicente RC, Cesário MD, Guirro RR. Cold-water immersion alters muscle recruitment and balance of basketball players during vertical jump landing. J Sports Sci. 2016;34(4):348-57.

13. Fukuchi CA, Rocha ES, Stefanyshyn DJ. Effects of cold water immersion on lower extremity joint biomechanics during running. J Sports Sci. 2015;33(5):449-56.

14. Mejia N, Dedow K, Nguy L, Sullivan P, Khoshnevis S, Diller KR. An on-site thermoelectric cooling device for cryotherapy and control of skin blood flow. J Med Device. 2015;9(4):1-6.

15. Ackermann DM, Foldes EL, Bhadra N, Kilgore KL. Nerve conduction block using combined thermoelectric cooling and high frequency electrical stimulation. J Neurosci Methods. 2010;193(1):72-6.

16. Okcu G, Yercan HS. Is it possible to decrease skin temperature with ice packs under casts and bandages? A crosssectional, randomized trial on normal and swollen ankles. Arch Orthop Trauma Surg. 2006;126(10):668-73. 
17. Enwemeka CS, Allen C, Avila P, Bina J, Konrade J, Munns S. Soft tissue thermodynamics before, during, and after cold pack therapy. Med Sci Sports Exerc. 2002;34(1):45-50.

18. MacAuley DC. Ice therapy: how good is the evidence? Int J Sports Med. 2001;22(5):379-84.

19. Rupp KA, Herman DC, Hertel J, Saliba SA. Intramuscular temperature changes during and after 2 different cryotherapy interventions in healthy individuals. J Orthop Sports Phys Ther. 2012;42(8):731-7.

20. Bleakley CM, McDonough SM, MacAuley. Cryotherapy for acute ankle sprains: a randomised controlled study of two different icing protocols. Br J Sports Med. 2006;40(8):700-5.

21. Chesterton LS, Foster NE, Ross L. Skin temperature response to cryotherapy. Arch Phys Med Rehabil. 2002;83(4):543-9.

22. Abramson DI, Chu LS, ThuckJr S, Lee SW, Richardson G, Levin M. Effect of tissue temperatures and blood flow on motor nerve conduction velocity. Jama. 1966;198(10):1082-8.

23. Stal F, Fransson PA, Magnusson M, Karlberg M. Effects of hypothermic anesthesia of the feet on vibration-induced body sway and adaptation. J Vestib Res. 2003;13(1):39-52.

24. Powers ME, Dover GC. A test of nerves. Rehab Manag. 2003;16(3):22-5.

25. Bleakley CM, O'Connor S, Tully MA, Rocke LG, Macauley DC, McDonough SM. The PRICE study (protection rest ice compression elevation): design of randomised controlled trial comparing standard versus cryokinetic ice applications in the management of acute ankle sprain. BMC Musculoskelet Disord. 2007;8:125.

26. Kernozek TW, Greany JF, Anderson DR, Van Heel D, Youngdahl RL, Benesh BG, et al. The effect of immersion cryotherapy on medial-lateral postural sway variability in individuals with a lateral ankle sprain. Physiother Rest Int. 2008;13(2):107-18.

27. Herrera E, Sandoval MC, Carmargo DM, Salvini TF. Motor and sensory nerve conduction are affected differently by ice pack, ice massage, and cold water immersion. Phys Ther. 2010;90(4):581-91.

28. Sartini LEM, Machado MO, Giovannini VF, Rocha TC. Efeitos da crioterapia sobre a estabilidade e equilíbrio estático e dinâmico. Braz J Hea Rev. 2018;1(2):399-420.
29. Kim KM, Hart JM, Saliba SA, Hertel J. Effects of focal ankle joint cooling on unipedal static balance in individuals with and without chronic ankle instability. Gait Posture. 2015;41(1):282-7.

30. Oliveira LF, Simpson DM, Nadal J. Calculation of area of stabilometric signals using principal component analysis. Physiol Meas 1996;17(4):305-12.

31. Instituto Nacional de Meteorologia. Banco de Dados Meteorológicos para Ensino e Pesquisa [cited 2020 Apr 6] Available from: https://portal.inmet.gov.br/

32. Kapteyn TS, Bles W, Njiokiktjien CJ, Kodde L, Massen CH, Mol JM. Standardization in platform stabilometry being a part of posturography. Agressologie. 1983;24(7):321-6.

33. Russo L, D’eramo U, Padulo J, Foti C, Schiffer R, Scoppa F. Day-time effect on postural stability in young sportsmen. Muscles Ligaments Tendons J. 2015;5(1):38-42.

34. Macedo CSG, Vicente RC, Cesário MD, Guirro RR. Coldwater immersion alters muscle recruitment and balance of basketball players during vertical jump landing. J Sports Sci 2016;34(4):348-57.

35. Janwantanakul P. The effect of quantity of ice and size of contact area on ice pack/skin interface temperature. Physiotherapy. 2009;95(2):120-5.

36. Stalman A, Berglund L, Dungnerc E, Arner P, FelländerTsai L. Temperature-sensitive release of prostaglandina E2 and dimished energy requirements in synovial tissue with postoperative cryotherapy: a prospective randomized study after knee arthroscopy. J Bone Joint Surg Am. 2011;93(21):1961-8.

37. Freire TR, Santana MMS, Farias Neto JP, Grigoletto MES, Silva Jr WM. Análise do desempenho físico e do equilíbrio sob influência da crioterapia em atletas de futsal. Rev Bras Med Esporte. 2015;21(6):480-4.

38. Nadler SF, Weingand K, Kruse RJ. The physiologic basis and clinical applications of cryotherapy and thermotherapy for the pain practitioner. Pain Physician. 2004;7(3):395-9.

39. Silva DA, Peixoto GFG, Rodrigues KMS, Farias VX. Eficácia analgésica da associação da crioterapia e da estimulação elétrica nervosa transcutânea. BrJP. 2018;1(3):274-8.

40. Hopper D, Whittington D, Davies J. Does ice immersion influence ankle joint position sense? Physiother Res Int. 1997;2(4):223-36. 
41. Uchio Y, Ochi M, Fujihara A, Adachi N, Iwasa J, Sakai Y. Cryotherapy influences joint laxity and position sense of the healthy knee joint. Arch Phys Med Rehabil. 2003;84(1):131-5.

42. Surenkok O, Aytar A, Tuzun EH, Akman MN. Cryotherapy impairs knee joint position sense and balance. Isokinet Exerc Sci. 2008;16(1):69-73.

43. Muaidi QI, Nicholson LL, Refshauge KM. Proprioceptive acuity in active rotation movements in healthy knees. Arch Phys Med Rehabil. 2008;89(2):371-6.

44. Gandevia SC, Refshauge KM, Collins DF. Proprioception: peripheral inputs and perceptual interactions. Adv Exp Med Biol. 2002;508:61-8.

45. Furmanek MP, Slomka KJ, Sobiesiak A, Rzepko M, Juras G. The effects of cryotherapy on knee joint position sense and force production sense in healthy individuals. J Hum Kinet. 2018;61:39-51.

46. Corrigan JP, Cashman WF, Brady MP. Proprioception in the cruciate deficient knee. J Bone Joint Surg Br. 1992;74(2):247-50.

47. Payne KA, Berg K, Latin RW. Ankle injuries and ankle strength, flexibility, and proprioception in college basketball players. J Athl Train. 1997;32(3):221-5.
48. Zazulak BT, Hewett TE, Reeves NP, Goldberg B, Cholewicki J. The effects of core proprioception on knee injury: a prospective biomechanical-epidemiological study. Am J Sports Med. 2007;35(3):368-73.

49. Wassinger CA, Myers JB, Gatti JM, Conley KM, Lephart SM. Proprioception and throwing accuracy in the dominant shoulder after cryotherapy. J Athl Train. 2007;42(1):84-9.

50. Dover G, Powers ME. Cryotherapy does not impair shoulder joint position sense. Arch Phys Med Rehabil. 2004;85(8):1241-6.

51. LaRiviere J, Osterning L. The effect of ice immersion on joint position sense. J Sport Rehabil. 1994;3(1):58-67.

52. Ozmun JC, Thieme HA, Ingersoll CD, Knight KL. Cooling does not affect knee proprioception. J Athl Train. 1996;31(1):8-11.

53. Evans TA, Ingersoll C, Knight KL, Worrell T. Agility following the application of cold therapy. J Athl Train. 1995;30(3):231-4.

54. Yanagisawa O, Homma T, Okuwaki T, Shimao D, Takahashi H. Effects of cooling on human skin and skeletal muscle. Eur J Appl Physiol. 2007;100(6):737-45.

Received: 04/02/2020

Recebido: 02/04/2020

Approved: 07/06/2020

Aprovado: 06/07/2020 